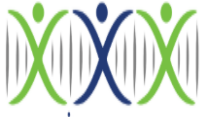

IRASD
Pakistan Journal of Humanities and Social Sciences

Volume 9, Number 3, 2021, Pages 340-350

Journal Homepage:

https://journals.internationalrasd.org/index.php/pjhss

\title{
The Shadow Economy in Pakistan: An Analysis with MIMIC Model
}

\author{
Ateeqa Jabbar ${ }^{1}$, Javed Iqbal ${ }^{2}$
}

${ }^{1}$ Ph.D. Scholar, Institute of Management Sciences, Bahauddin Zakariya University, Multan, Pakistan. Email: atiqa_jabbar@hotmail.com

${ }^{1}$ Assistant Professor, Institute of Management Sciences, Bahauddin Zakariya University, Multan, Pakistan. Email: javediabal@bzu.edu.pk

\section{ARTICLE INFO}

Article History:

Received:

Revised:

Accepted:

Available Online: December 08, 2021

\section{Keywords:}

Business Freedom

Government Integrity

Monetary Freedom

Shadow Economy

MIMIC Model

October 06, 2021

December 01, 2021

December 06, 2021

08,2021

\section{ABSTRACT} period 2011 to 2021 . The results indicate that the tax burden, business freedom, unemployment rate and Gross Domestic Product are the key driving forces of the shadow economy in Pakistan. The findings are potentially beneficial for the policymakers in identifying and dealing with the shadow economic activities as well as developing the strategies relevant to the economic policy.

(C) 2021 The Authors, Published by iRASD. This is an Open Access Article under the Creative Common Attribution Non-Commercial 4.0 Corresponding Author's Email: javediqbal@bzu.edu.pk

\section{Introduction}

Around the world, a robust indication of shadow economic activities has enhanced. Various penal measures, social security system and tax reforms utilize to control such activities and straighten the path of improvement in official economy dynamics. In a shadow economy, effective decision making of economic policy rely on the statistical accuracy of country resource allocation (Schneider \& Enste, 2000).

The shadow economy, a fundamental slice of an unobservable economy, unlike other aspects it is out of boundary of legal framework at the same time, it involves in the legal supply of goods and services production, in contrast to the activities profiting through illegal manners of reallocating income and values, named as criminal economy (Bashlakova \& Bashlakov, 2020). The term shadow economy reflects the activities purely based on the circumvention of governmental regulation, surveillance or taxation and often referred to as black economy, hidden economy, informal economy, undeclared economy and underground economy. The shadow economy, an adverse yet inevitable attendant, aimed to shrink its size through control measures, legislation and policy implications, hence measurability is still a significant and vital issue (Tiszberger, 2019).

Particularly, wide shadow economy under emerging economies having a clear considerate that country's economic development is influenced by financial inclusion (Hajilee et al., 2017). Generally, the decision making of macroeconomic policy from specious data based on a source such as shadow economy is truly undesirable. For the establishment of effective public policies, a steadfast knowledge of shadow economy size is considered as an essential prerequisite (Dell'Anno, 2016). The interpretation of shadow economy for government is a hypothetically grave damage of revenue, consequently honest citizens bear an unfair burden and conceivable less funding of services for public. As a part of unrecorded economic activities, primarily for the evasion of tax payments is considered under the criminal activities (Orviska et al., 2006). 
Across the globe, shadow economies are extensively prevalent while various factors involve in oblivion of economic activities and deriving business towards underground is existent even in countries like Scandinavian countries (Schneider et al., 2010 and Tanzi, 1999). Such activities lead the firms towards tax evasion as well as avoiding rules and regulations (Goel \& Nelson, 2016).

In this study, the causal variables (i.e. tax burden, business freedom, unemployment rate, GDP per capita, government integrity, and fiscal freedom) significantly affect the size of shadow economy in Pakistan and whether the shadow economy size determine and alleviate the performance of macroeconomic indicators (growth rate of GDP, labor freedom and monetary freedom). Structural association of multiple causal variables with the shadow economy influences its size.

An overall model fit evaluation is the basis behind the selection of MIMIC Model. The model fit evaluation ensures the informative interpretation of parametric estimates of the population through maintaining the model-implied covariance within the range of population covariance. The MIMIC Model measured the impact of causal variables on the indicator variable through the sum of direct and indirect effect (Ramlall, 2016). The MIMIC Model of Jöreskog \& Goldberger (1975), consists of a covariance association among exogenous causal variables, a latent variable and observable indicator variables, which helps to identify latent variable indices as well as to estimate the effect of several factors on these indices (Richards \& Jeffrey, 2000).

The MIMIC modeling basically applied to time series data for the estimation of the size and development of the shadow economy. A problem of bogus regression may originate because most of the macroeconomic variables do not fulfil the fundamental assumption of stationarity (Buehn \& Schneider, 2008). The MIMIC Model represents a mixture of econometric and psychometric themes, which perceives multiple causes and multiple indicators of a solitary latent variable (Chen, 1981).

So, this structural equation modeling method (MIMIC Model) displays a number of ibserved causal variables referred to as supreme imperative determinants of economic activities which are not reported and a set of observable indicator variables regarded as change in the size of shadow economy (Dell'Anno \& Davidescu, 2018). The rest of the paper is distributed as literature review and hypothesis development, methodology, results discussion and conclusion.

\section{Literature Review}

Frequently used definition of shadow economy includes the contribution of unregistered economic activities in the formal computation of GNP (Gross National Product). Another definition explains it as the economic activities and their derived income that evade government regulation, observation or taxation or otherwise (Schneider, 2005). Smith (1994) define the shadow economy as the market based legal and illegal production of goods and services that avoids being detected by official GDP estimates.

According to Schneider (2010), all types of legal market-base production of goods and services that are purposively hidden from public authorities just to evade payments of value added, other taxes or income and social security contributions; to meet the certain standards of labor market. Hoinaru et al., (2020), suggested that shadow economy refers to economic activities hidden from government rather than illegal activities that yield drug trafficking, hidden income, hiring of illegal immigrants, illegal branding of goods, illegal gambling, loan sharking, prostitution and tax fraud. According to the Dell'Anno \& Davidescu (2019), an imperative policy aim, fighting the shadow economy (S.E) as well as tax evasion (T.E) necessitates the information of the reasons and extent to which people are involved in irregular economic activities.

The substitute descriptions of shadow economy must be shaped in a significant style that specific underground economic activities ought to diversify the aspects of economic inquest (Dell'Anno, 2007). Goel \& Nelson (2016) suggested an innovative econometric technique, elaborated the importance of potential determinant of shadow economy on the 
basis of statistical robustness, and provided a clear differentiation amid new shadow operators and established underground entrepreneurs.

A growing stream of literature suggested that shadow economic activities can be regulated through the causal determinants. Buehn et al., (2009) concluded that hidden economy spectrum and shadow economic activities have significant positive association with social security contribution and tax burden. Schneider (2009) depicted that various driving forces such as tax burden, social security payment, state institution quality, labor market regulation and tax morale, intensively influenced the shadow economy.

Mazhar \& Méon (2017) demonstrated the movement of causal effects from inflation and tax burden to the size of shadow economy and is considered the prime reason for tax evasion thus driving the tax and monetary policies. In a similar study, unemployment rate is negatively related to the size and growth of the shadow economy in Egypt (Hassan \& Schneider, 2016). Alanon \& Gómez-Antonio (2005) and Macias \& Cazzavillan (2010) determined that a high level of unemployment does not inevitably approach to a greater size of shadow economy in Spain and Mexico, respectively.

Trade and economic liberalization policies can moderate the enlargement of shadow economy size. The Egyptian policies related to economic liberalization have significant declining impact on the shadow economy size as a percentage of GDP (Gross Domestic Product) (Farzanegan et al., 2020). On the contrary, Bashlakova \& Bashlakov (2020) shown the inefficient regulation of fiscal, monetary and institutional regulation in an economic system produces the inevitable outcome of overlooking the specific shadow economic weight in gross domestic product (GDP) specially in Russia and China.

A normative perspective recommends the spending of government and its macroeconomic policy to reduce the shadow economy such as Tanzania (Dell'Anno \& Davidescu, 2018). Dell'Anno (2007) documented that the empirical results suggest three main pillars, (a) to improve the regulation of taxes independently employed, (b) to enhance the public sector efficiency with a rise in economic freedom, (c) to reform the social security benefits particularly for unemployed people in order to diminish the Portuguese shadow economy. Hence, to estimate the causal effect, it is hypothesize:

$\mathbf{H}_{1}$ : The shadow economy have diverse causal variables (tax burden, business freedom, unemployment rate, GDP per capita, government integrity and fiscal freedom) affecting its size in Pakistan.

Hajilee et al., (2017) suggest the equity of income and poverty reduction as a core financial inclusion challenge to reduce the size of shadow economy. Dell'Anno \& Solomon (2008) found that the shadow economy plays a beneficial role in minimizing the influence of unemployment rate on the official economy. Bashlakova \& Bashlakov (2020) provided empirical evidence that real GDP as against Gross GDP when recorded in a legal manner have different effects on the shadow economy. Schneider \& Enste (2000) illustrated that the causal analysis depicted an impact of plenty of major driving aspects, enhancement in social security contribution and tax burden as well as growing labor market restrictions and governmental regulatory activities, on the size and growth of the shadow economy.

Schneider \& Williams (2013), Buehn \& Farzanegan (2013) and Dell'Anno et al., (2007) concluded that the official economy is negatively associated with the size of shadow economy in France Greece and Spain. Hassan \& Schneider (2016) reported that the shadow economy size accounts for a vast burden on the official economy approaching to some adverse externalities which ultimately participate in hindering the growth and development of country. Dell'Anno (2016) found that the reduction in the official gross domestic product (GDP) is the primarily chief result of the positive correlation between inequality and shadow economic ratio.

Research by several scholars, there is a statistically significant positive association between currency in hand by public and the size of shadow economy when analyzed through MIMIC Model containing money growth as a key indicator (Buehn \& Farzanegan 2013, Schneider et al., 2010, Dell'Anno et al., 2007, Alanon, \& Gómez-Antonio 2005 and Hassan \& 
Schneider 2016). Hoinaru et al., (2020) resulted that the countries with low-income extremely characterized by poverty driven syndromes generate the greater size of corruption and the shadow economy which is related to the sustainable and lower economic expansion.

According to the Torgler \& Schneider (2009), the higher level of institutional quality and tax morale lead to smaller size of shadow economy. The widespread corruption and poorly spent burden of taxation leads to the growth of informal sector. Conversely, the responsible interaction between citizens and authorities reflects more effective policies and better governed institutional structures, ultimately influenced the behavioral performance of government (Schaltegger \& Torgler, 2007). Based on above discussion, the authors suggest to inquire the following proposition:

H2: The higher level of shadow economy have a negative relationship with labor freedom.

H3: The greater size of shadow economy will lead to a decrease in the growth rate of GDP.

$\mathbf{H}_{4}$ : An increase in the size pf shadow economy will cause a rise in the monetary freedom.

\section{Methodology}

\subsection{Data and Sample characteristics}

The data for Pakistan for the sampling period 2011-2021 is collected from the official websites of Heritage Foundation's economic freedom index. The MIMIC Model as a structural equation modeling (SEM) method based on the statistical theory of unobserved (latent) variable was established in 1970, and is being utilized in psychometrics as well as social sciences research (Zellner, 1970 and Jöreskog \& Goldberger, 1975). The pioneer of this approach, Frey \& Weck-Hanneman (1984), applied MIMIC to estimate the size of shadow economy in OECD countries for multiple years.

Consistent with the prior literature, generally causal variables that impact on the shadow economy growth rate are: tax burden, business freedom, unemployment rate, GDP per capita, government integrity and fiscal freedom. Tax Burden, a composite measure indicates the marginal tax rate on individual income as well as corporate income and the overall tax comprising direct and indirect taxation by the government as a proportion of GDP (Gross Domestic Product). Business Freedom estimates the degree to which the infrastructure and regulatory environments compel the effectual operational activities of businesses. The ease of business activities (starting, operating and closing) affected by a set of factors involved to derive this quantitative score. The score of business freedom for a country is a number ranges from 0 to 100, where 100 is indicative of the freest environment of a business. Unemployment Rate is measured through the slice of a workforce actively involved in work striving but not get employed.

GDP per Capita, a variable reflects per capita value GDP regulated for purchasing power parity (PPP) represented in present international dollars. Government Integrity, the systematic corruption corrodes the economic freedom through regulating constraints and insecurity into economic relations. The score of government integrity score calculated by average score of bribes and irregular payments, absence of corruption, corruption perception, clarity of government policymaking, and transparency of government and civil service. Fiscal Freedom, a country's fiscal health face erosion owing to debt burden enhancement and deficit extensiveness instigated through poorly managed budget by government. In turn, economic vagueness and macroeconomic volatility leads to deterioration of fiscal health. The fiscal health component measure the score based on both average deficits and debt as a percentage of GDP.

To estimate the development of shadow economy, the model contains indicator variables as, labor freedom, growth rate of GDP and monetary freedom. Labor Freedom, a quantitative composite measure intends diverse aspects of legal and governing labor market framework comprising regulations regarding laws hindering layoffs, minimum wages and requirements of severance as well as computable governing restraints on working hours and employees hiring, additionally estimate the labor force participation rate considers as representative of employment opportunities available for labors in the market.

Growth rate of GDP, the real Gross Domestic Product (GDP) growth rate calculated through continual currency unit and percentage changes occur on annual basis. Monetary 
Freedom, a component based on combination of average rate of inflation and qualitative judgment of several governmental activities involved in price distortion. Price stability considers an ideal state in the absence of microeconomic intervention particularly in free markets. Broadly speaking, the association among the prevalence of the shadow economy, the causal factors and the indicators organized as follows:

\section{Figure 1: Relationship between the shadow economy, causal variables and} indicator variables

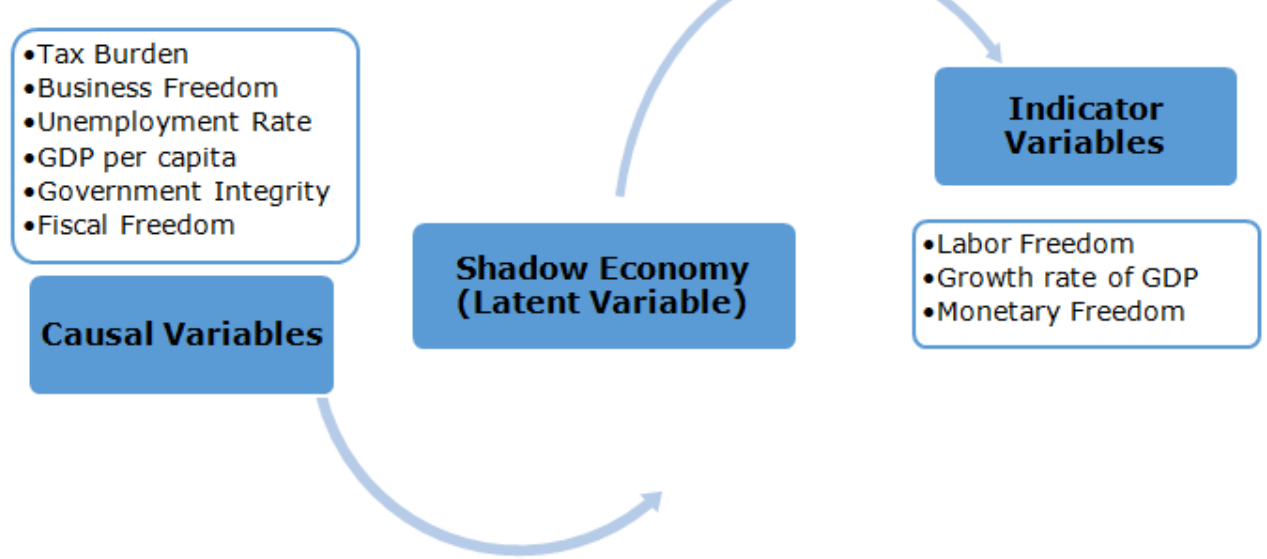

In this paper, the multiple causes multiple indicators model has the simultaneous specification of a structural model and a measurement model. The structural model specified the association between the latent (unobserved) variable and the explanatory causal (observed) variables, whereas the measurement model represented the link between the latent variable and the macroeconomic indicator variables. In this motive, the MIMIC Model focuses on testing of derived hypothesis and assessing the structural theory's consistency through empirical data and aims; (i) Estimation of the parameters (ii) Assessment of model fitness. This econometric model contains equations (Structural and Measurement) with particular specifications as follows:

$$
\begin{aligned}
& \text { S.E it }=\beta_{0}+\beta_{1} \text { T.B it }+\beta_{2} \text { B.F it }+\beta_{3} \text { U.R it }+\beta_{4} \mathrm{GDP}_{\text {it }}+\beta_{5} \text { G.I it }+\beta_{6} \mathrm{~F}_{\text {. F }} \text { it }+\varepsilon_{\text {it }} \\
& \text { L.F } F_{\text {it }}=\lambda_{1}+\alpha_{1} \text { S.E } E_{\text {it }}+\varepsilon \varepsilon_{1 \text { it }} \\
& \text { GDPRATE it }=\lambda_{2}+\alpha_{2} \text { S.E } E_{\text {it }}+\varepsilon 2 \text { it } \\
& \text { M.F it }=\lambda_{3}+\alpha_{3} S_{\text {S. }} \text { it }+\varepsilon 3 \text { it }
\end{aligned}
$$

Where, S.E it $=$ Shadow Economy during period $\mathrm{t}, \mathrm{T} . \mathrm{B}$ it $=$ Total Tax Burden, B.F it $=$ Business Freedom, U.R it $=$ Unemployment Rate during period $t$, GDP it $=$ Gross Domestic Product per capita during period $t, G . I$ it $=$ Government Integrity, F.F it $=$ Fiscal Freedom, L.F it $=$ Labor Freedom, GDPRATE it $=$ Growth rate of GDP per capita, M.F it $=$ Monetary Freedom and $\varepsilon_{\text {it }}=$ Error term.

\section{Analysis}

In this research, an analytical depiction of MIMIC Model with the supreme general specification as MIMIC 6-1-3 (six causal variables, one latent variable and three indicator variables) is applied to estimate the growth of shadow economy in Pakistan. According to this MIMIC Model (6-1-3), the causal variables include tax burden, business freedom, unemployment rate, GDP, government integrity and fiscal freedom, shadow economy as a latent variable and the indicator variables are labor freedom, GDP growth and monetary freedom as shown below.

The fundamental framework of this MIMIC Model, is able to comprehensively evaluate the shadow economy through starting from the supreme general specification (MIMIC 6-1-3) to the ultimate significant parametric specification (MIMIC 4-1-3) by eliminating the variables of non-significant path. Consequently, starting from MIMIC 6-1-3 and deleting the nonsignificant tracks, it is the best model regarding to the statistical properties. 
Figure 2: Structural relationship between the shadow economy, causal variables and indicator variables

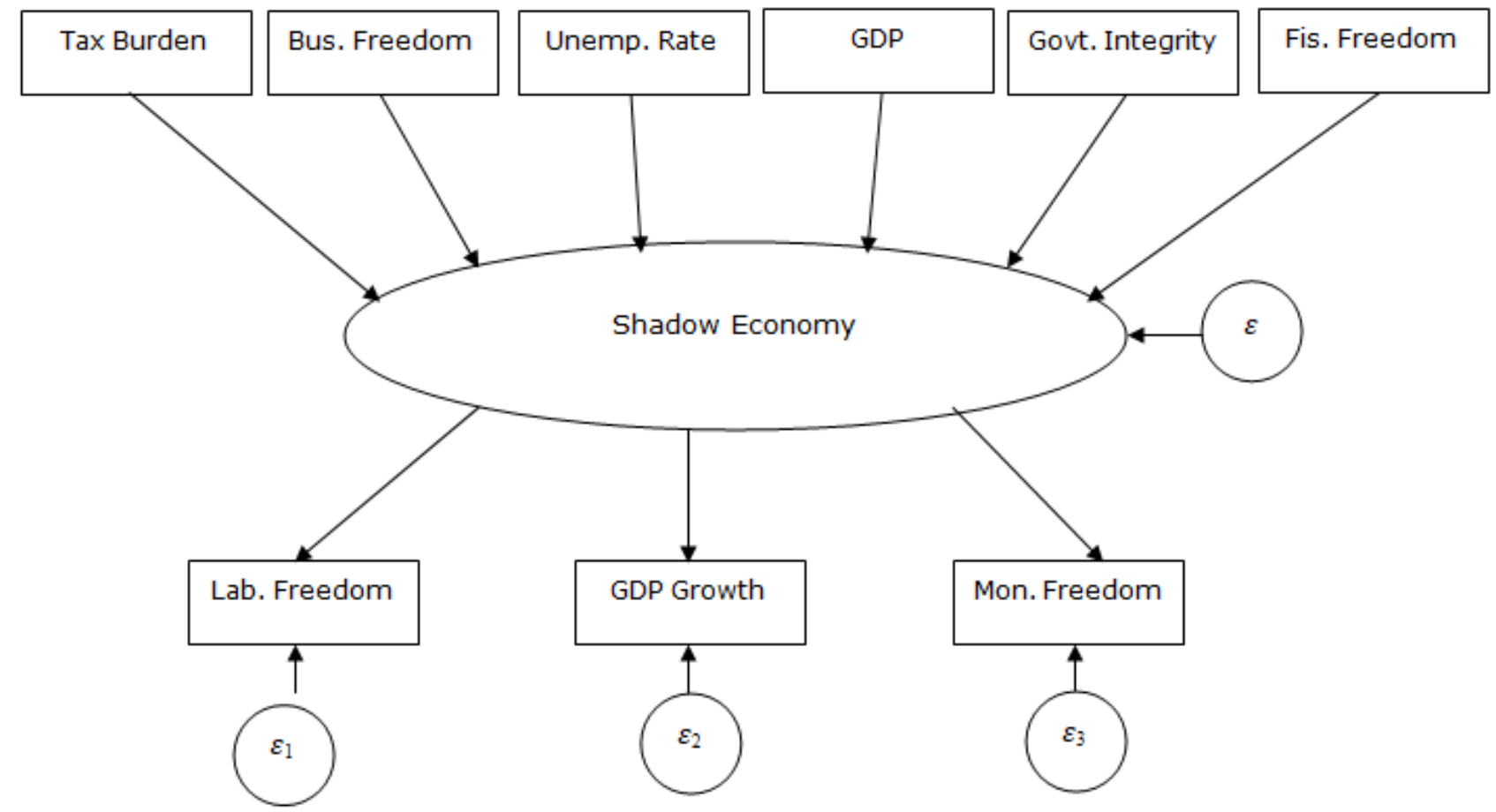

Table 1: MIMIC Model (Multiple Indicators Multiple Causes Model)

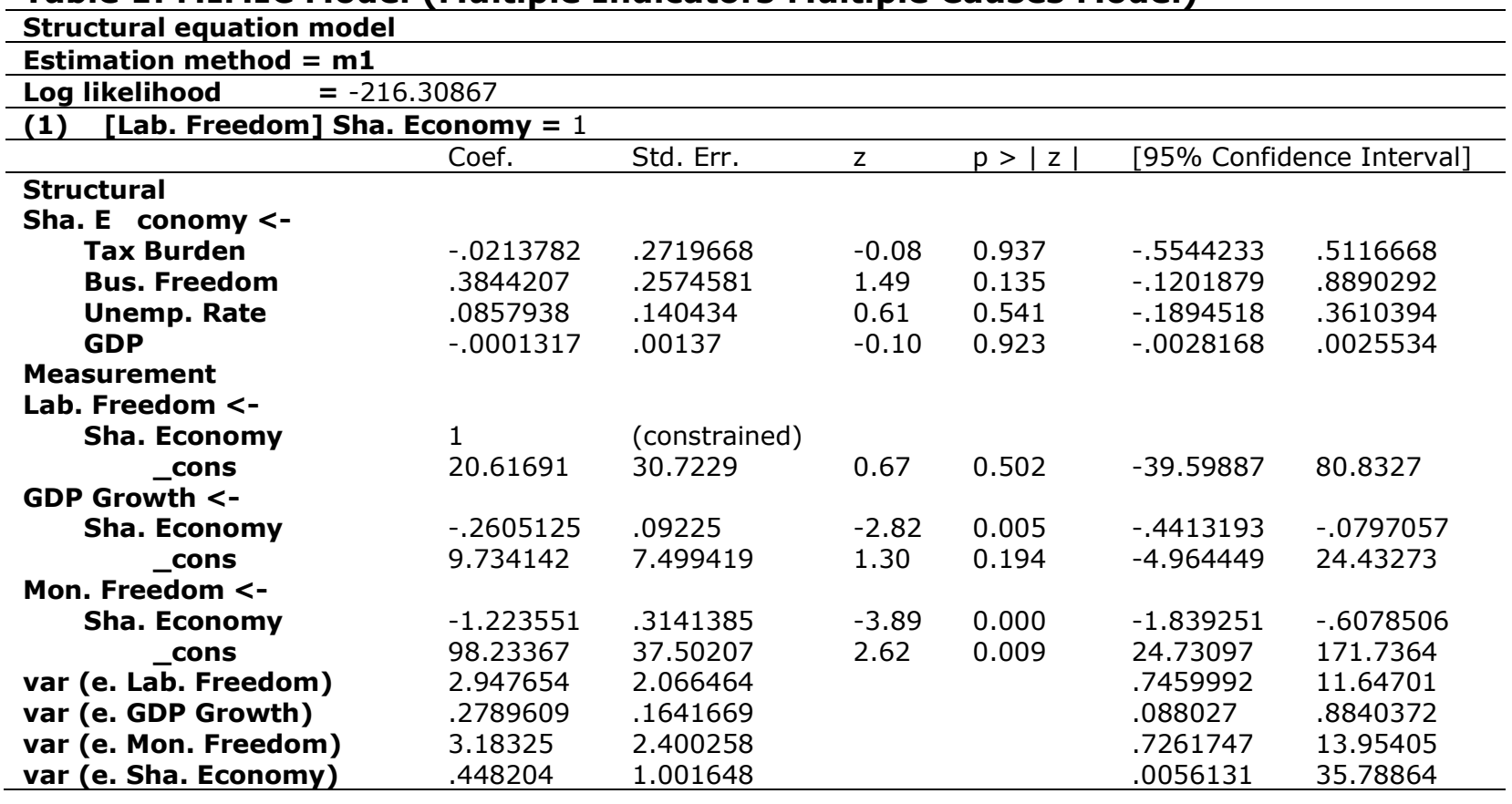

In this model, the observed variables tax burden, business freedom, unemployment rate and Gross Domestic Product (GDP) treated as predictors of shadow economy has positive as well as negative coefficients regarding latent variable shadow economy in structural model. The structural equation model, the causal variables business freedom and unemployment rate both have positive coefficients indicate their positive interaction with the size of shadow economy. The increase in both business freedom and unemployment rate lead to the enhancement in the shadow economy activities in Pakistan and the vice versa is very true. While, the tax burden and GDP per capita negatively associated with shadow economy through reflecting their coefficient values as -.0213782 and -.0001317 respectively. The coefficient sign of the causal variables, implying that the increase/decrease in their values will lead to the respective change in Pakistan's shadow economic activities nevertheless of industry or sector. All the multiple causal variables are highly insignificant at $5 \%$ level, in determining the movements in shadow economic activities. 
The measurement model of MIMIC analysis exhibits the linkage between the shadow economy and the three multiple macroeconomic indicators, labor freedom, growth rate of Gross Domestic Product (GDP) and monetary freedom. In the estimation of measurement model, the negative coefficients indicate that an increase (decrease) in the size of shadow economy leads to low (high) growth in Gross Domestic Product (GDP) and decrease (increase) in the monetary freedom indicator. On the other hand, the shadow economy has a positive and statistically insignificant relationship with the labor freedom. In the case of remaining indicators, both the GDP growth and monetary freedom are statistically significant with the values 0.005 and 0.000 respectively. In the case of structural model, the goodness of fit is a measure of well fitted observed moments of covariance but in measurement model expected fundamental causes are unobserved. The required values diverge from test to test.

Table 2: Goodness-of-fit Statistics

\begin{tabular}{ccc}
\hline Fit statistic & Value & Description \\
\hline Likelihood ratio & 15.476 & model vs. saturated \\
chi' $^{\mathbf{2}}$ - $\mathbf{m s}(\mathbf{8})$ & 0.051 & \\
$\mathbf{p}>$ chi $^{\mathbf{2}}$ & 53.901 & baseline vs. saturated \\
$\mathbf{c h i} \mathbf{i}^{\mathbf{2}} \mathbf{\text { bs }} \mathbf{( 1 5 )}$ & 0.000 & \\
$\mathbf{p}>\mathbf{c h i}^{\mathbf{2}}$ & & \\
\hline
\end{tabular}

Table 3: Equation-level goodness of fit Statistics

\begin{tabular}{|c|c|c|c|c|c|c|}
\hline depvars & fitted & $\begin{array}{l}\text { Variance } \\
\text { predicted }\end{array}$ & residuals & $\begin{array}{c}\text { R- } \\
\text { squared }\end{array}$ & mc & $\mathbf{m c}^{2}$ \\
\hline \multicolumn{7}{|c|}{ Observed } \\
\hline Lab. Freedom & 10.681 & 7.733349 & 2.947654 & .7240284 & .8508986 & .7240284 \\
\hline GDP Growth & .8037983 & .5248374 & .2789609 & .6529467 & .8080512 & .6529467 \\
\hline Mon. Freedom & 14.76066 & 11.57741 & 3.18325 & .7843424 & .8856311 & .7843424 \\
\hline \multicolumn{7}{|c|}{ Latent } \\
\hline $\begin{array}{c}\text { Sha. Economy } \\
\text { Overall }\end{array}$ & 7.733349 & 7.285145 & .448204 & $\begin{array}{l}.9420427 \\
.9420427\end{array}$ & .9705888 & .9420427 \\
\hline
\end{tabular}

Table 4: Residuals of Observed Variables

\begin{tabular}{|c|c|c|c|c|c|c|c|}
\hline \multicolumn{4}{|c|}{ Mean residuals } & & & & \\
\hline & $\begin{array}{c}\text { Lab. } \\
\text { Freedom }\end{array}$ & $\begin{array}{c}\text { GDP } \\
\text { Growth }\end{array}$ & $\begin{array}{c}\text { Mon. } \\
\text { Freedom }\end{array}$ & $\begin{array}{c}\text { Tax } \\
\text { Burden }\end{array}$ & $\begin{array}{c}\text { Bus. } \\
\text { Freedom }\end{array}$ & $\begin{array}{l}\text { Unemp. } \\
\text { Rate }\end{array}$ & GDP \\
\hline raw & -0.000 & -0.000 & 0.000 & 0.000 & 0.000 & 0.000 & 0.000 \\
\hline \multirow[t]{3}{*}{ normalized } & -0.000 & -0.000 & 0.000 & 0.000 & 0.000 & 0.000 & 0.000 \\
\hline & \multicolumn{7}{|c|}{ Covariance residuals } \\
\hline & $\begin{array}{c}\text { Lab. } \\
\text { Freedom }\end{array}$ & $\begin{array}{c}\text { GDP } \\
\text { Growth } \\
\end{array}$ & $\begin{array}{c}\text { Mon. } \\
\text { Freedom }\end{array}$ & $\begin{array}{c}\text { Tax } \\
\text { Burden } \\
\end{array}$ & $\begin{array}{c}\text { Bus. } \\
\text { Freedom }\end{array}$ & $\begin{array}{l}\text { Unemp. } \\
\text { Rate }\end{array}$ & GDP \\
\hline Lab. Freedom & -0.000 & & & & & & \\
\hline GDP Growth & 0.0298 & 0.000 & & & & & \\
\hline Mon. Freedom & -0.929 & -0.075 & 0.000 & & & & \\
\hline Tax Burden & 1.623 & 0.596 & -0.014 & 0.000 & & & \\
\hline Bus. Freedom & -0.113 & -0.714 & 0.324 & 0.000 & 0.000 & & \\
\hline Unemp. Rate & 0.254 & 0.291 & -0.484 & 0.000 & 0.000 & 0.000 & \\
\hline \multirow[t]{3}{*}{ GDP } & -159.078 & 25.52 & -202.41 & 0.000 & 0.000 & 0.000 & 0.000 \\
\hline & \multicolumn{7}{|c|}{ Normalized covariance residuals } \\
\hline & $\begin{array}{c}\text { Lab. } \\
\text { Freedom }\end{array}$ & $\begin{array}{c}\text { GDP } \\
\text { Growth }\end{array}$ & $\begin{array}{c}\text { Mon. } \\
\text { Freedom }\end{array}$ & $\begin{array}{c}\text { Tax } \\
\text { Burden }\end{array}$ & $\begin{array}{c}\text { Bus. } \\
\text { Freedom }\end{array}$ & $\begin{array}{l}\text { Unemp. } \\
\text { Rate }\end{array}$ & GDP \\
\hline $\begin{array}{l}\text { Lab. Freedom } \\
\text { GDP Growth }\end{array}$ & $\begin{array}{l}-0.000 \\
0.278\end{array}$ & 0.000 & & & & & \\
\hline Mon. Freedom & -0.196 & -0.059 & 0.000 & & & & \\
\hline Tax Burden & 0.817 & 1.095 & -0.006 & 0.000 & & & \\
\hline Bus. Freedom & -0.015 & -0.084 & 0.035 & 0.000 & 0.000 & & \\
\hline Unemp. Rate & 0.058 & 0.246 & -0.093 & 0.000 & 0.000 & 0.000 & \\
\hline GDP & -0.108 & 0.064 & -0.115 & 0.000 & 0.000 & 0.000 & 0.000 \\
\hline
\end{tabular}

The first test is a reflection of model $X^{2}$ test and the second test is a model comparison between baseline and saturated model. The baseline model consists of mean values and variances of observed causal variables as well as the covariance of exogenous variables having 
observed values. Whereas, the saturated model is about the perfectly fits the covariance in the model. Mostly, the rejection level is $5 \%$ or any other level that fits the model, baseline model and saturated model as well. The value of $R^{2}$ is 1 means the model is a good fit and in the given table the value of $R^{2}$ is .9420427 , which is closer to 1 indicates a good fit.

The residuals analysis plays a significant role in the model validation and the structural equation modeling (SEM) fits the means and covariances. In the SEM sense, residuals thus allude to means and covariances. The residuals are apportioned into two subgroups; (1) the mean residuals, consist of the raw residuals and the normalized residuals, (2) the covariance residuals, concern with the normalized covariance residuals. The normalized covariance residuals attempt to regulate the residuals in the same manner as the standardized residuals. The normalized covariance residuals are always considered as valid and a standard normal distribution is not followed by them but by standardized covariance residuals. The covariance residuals between GDP and GDP Growth having 25.52, the highest value.

Table 5: Size and development of the Shadow Economy of Pakistan estimated by MIMIC Model over the period 2011 to 2021

\begin{tabular}{lccc}
\hline Years & SE & Official GDP & Size of Shadow Economy \\
\hline $\mathbf{2 0 1 1}$ & 26.38515 & 435.8 & $6.05 \%$ \\
$\mathbf{2 0 1 2}$ & 26.10571 & 464.9 & $5.62 \%$ \\
$\mathbf{2 0 1 3}$ & 25.57877 & 488.6 & $5.24 \%$ \\
$\mathbf{2 0 1 4}$ & 25.23691 & 515.4 & $4.90 \%$ \\
$\mathbf{2 0 1 5}$ & 23.58833 & 575 & $4.10 \%$ \\
$\mathbf{2 0 1 6}$ & 21.66008 & 882.3 & $2.45 \%$ \\
$\mathbf{2 0 1 7}$ & 21.64461 & 931 & $2.32 \%$ \\
$\mathbf{2 0 1 8}$ & 19.41408 & 988.2 & $1.96 \%$ \\
$\mathbf{2 0 1 9}$ & 19.4826 & 1057 & $1.84 \%$ \\
$\mathbf{2 0 2 0}$ & 18.89523 & 1141.4 & $1.66 \%$ \\
$\mathbf{2 0 2 1}$ & 21.42247 & 1201.6 & $1.78 \%$ \\
\hline
\end{tabular}

The values of shadow economy (latent variable) ranges from 18.89523 to 26.38515 using the MIMIC Model. The size of shadow economy calculated as a percentage of official GDP. The analysis of MIMIC Model reveals that the size of shadow economy lies between $1.66 \%$ to $6.05 \%$ and it depicts a gradually decreasing trend in the shadow economy values but a slight increase occur in 2021 from $1.66 \%$ to $1.78 \%$.

Table 6: Estimated Coefficients of MIMIC Models and goodness-of-fit Statistics

\begin{tabular}{cccc}
\hline Models & MIMIC 6-1-3 & MIMIC 5-1-3 & MIMIC 4-1-3 \\
\hline Tax Burden & -0.25887 & 0.224769 & -0.02138 \\
Bus. Freedom & 0.369305 & -0.05885 & 0.384421 \\
Unemp. Rate & 0.050359 & 0.030117 & 0.085794 \\
GDP & -0.00017 & -0.00285 & -0.00013 \\
Lab. Freedom & 1 & 1 & 1 \\
GDP Growth & -0.3071 & -0.32074 & -0.26051 \\
Mon. Freedom & -1.26091 & -1.36941 & -1.22355 \\
\hline & Goodness-of-fit Statistics & \\
\hline Chi-Square $\left(\mathbf{X}^{\mathbf{2}}\right)$ & 65.834 & 54.101 & 53.901 \\
SRMR & 0.393 & 0.554 & 0.077 \\
Degree of Freedom & 14 & 13 & 13 \\
\hline
\end{tabular}

We have thoroughly discussed MIMIC Model (4-1-3) as the best model getting after removing the non-significant paths. For the explanation purposes, reproducing the results for experiment are related to MIMIC (6-1-3) and MIMIC (5-1-3) in the above table. A direct comparison of estimated coefficients is given just to evaluate the relative weights utilized for the explanation of shadow economy dynamics. Explicitly, the estimation results disclose that the main causal variables of shadow economy are tax burden, business freedom, unemployment rate and GDP, comprised in the MIMIC Model. Whereas, goodness-of-fit statistics includes chi-square values in decreasing order from 65.834 to 53.901. The standardized root mean squared residual (SRMR) measures the size of residuals. A perfect fit resembles to a SRMR of zero and its small value is considered as good fit. The ultimate limited 347 
value of SRMR is considered as 0.08 and the MIMIC Model (4-1-3) is at 0.077 which shows that the model fits well.

\section{Conclusion}

A key contribution reclines in engaging a novel econometric approach to regulate the statistical vigor of potential determinants of shadow economy. From a positive perspective, according to the finest significant parametric specification model MIMIC 4-1-3 (four causal variables, one latent variable and three indicator variables), the size of shadow economy with the reference to the Gross Domestic Product (GDP), ranges from $1.66 \%$ to $6.05 \%$ of the official GDP. The decreasing values of shadow economy from 2018 to 2020, require an econometric explanation which is considered as a consequence of interaction amid numerous observed causal variables which eventually evolve contrarily.

The general findings suggest that business freedom and unemployment rate, from the group of causal variables, contributed to enhance the shadow economic activities in Pakistan. While, the remaining causes tax burden and GDP per capita bring the fluctuations in the size of shadow economy through their negative association with shadow economy. In the same vein, the results show that the shadow economy has positive and negative relation with unemployment rate and tax burden, respectively (Buehn et al., 2009). According to the fiscal policy, more regulations and reforms are needed, in order to diminish the size of shadow economy, through mainly focusing on decreasing the tax rates, tax base enhancement and bureaucracy in tax payments (Dell'Anno \& Davidescu, 2018).

Lastly, the study found that the development in business freedom, rising the unemployment rate, restrictions on tax burden and reduction in labor freedom as well as monetary freedom are the main driving forces play a vital role in the growth of shadow economy. Same as Schneider et al., (2015) declared the tax evasion and unemployment as driving forces of the shadow economy. In this research study, it is demonstrated that the MIMIC Model appropriately measures the shadow economy size, which is predominantly beneficial for the economists trying to track the growth and collect the precise statistical values for the shadow economy, and ultimately to attain the research development in such a dubious area of statistics. The results of MIMIC Model are of practical relevance to all the participants contributing in the policy arena, enable the policy makers to implemented the concrete policy estimates and aware of few imperative aspects to determine the boundaries of relevant field. The precision of resulted estimates provide benefits to the policy makers in dealing with the shadow economic activities and in formulating of strategies related to economic policy.

In this study, the estimation of the shadow economy is facing some challenges i.e. small sample size, interpretation of the latent variable and the exogenous measures to regulate the model. The main limitations regarding MIMIC Model include: 1) owing to nonnormality and non-stationarity of the time-series, the MIMIC Model is applied to the time series analysis and a small sized sample, 2) the selection of observed variable as a casual variable or an indicator variable is another imperative challenge. For instance, unemployment rate as a causal variable is utilized to estimate the shadow economy. Simultaneously, unemployment rate can be considered as an indicator variable to interpret its impact on the existence and development of shadow economy in a particular country. The findings of his study will contribute as a reference point for future researchers in the field of finance. The values of shadow economy as a percentage of GDP will be utilize as a proxy of tax evasion and evaluate the tax evading effects on the economy. It is suggested that future scholars can conduct research to investigate the impact of country-level governance regarding tax evasion on the firm-level governance (Tax Evasion). Further, the study can expand to examine that this tax evading behavior of the firm ultimately influence its financial performance. Elaborating that how the shadow economy interferes with the economic, international and political phenomena referred to as an avenue for the future research.

\section{References}

Alañón*, A., \& Gómez-Antonio, M. (2005). Estimating the size of the shadow economy in Spain: a structural model with latent variables. Applied Economics, 37(9), 1011-1025. 
Bashlakova, V., \& Bashlakov, H. (2020). The study of the shadow economy in modern conditions: Theory, methodology, practice. The Quarterly Review of Economics and Finance, 81, 468-480.

Buehn, A., Karmann, A., \& Schneider, F. (2009). Shadow economy and do-it-yourself activities: the German case. Journal of Institutional and Theoretical Economics (JITE)/Zeitschrift für die gesamte Staatswissenschaft, 701-722.

Buehn, A., \& Farzanegan, M. R. (2013). Impact of education on the shadow economy: Institutions matter. Economics Bulletin, 33(3), 2052-2063.

Buehn, A., \& Schneider, F. (2008). MIMIC models, cointegration and error correction: An application to the French shadow economy.

Chen, C. F. (1981). The EM approach to the multiple indicators and multiple causes model via the estimation of the latent variable. Journal of the American Statistical Association, 76(375), 704-708.

Dell'Anno, R. (2007). The shadow economy in Portugal: An analysis with the MIMIC approach. Journal of Applied Economics, 10(2), 253-277.

Dell'Anno, R., Gómez-Antonio, M., \& Pardo, A. (2007). The shadow economy in three Mediterranean countries: France, Spain and Greece. A MIMIC approach. Empirical Economics, 33(1), 51-84.

Dell'Anno, R., \& Solomon, O. H. (2008). Shadow economy and unemployment rate in USA: is there a structural relationship? An empirical analysis. Applied economics, 40(19), 25372555.

Dell'Anno, R. (2016). Analyzing the determinants of the shadow economy with a "separate approach". An application of the relationship between inequality and the shadow economy. World Development, 84, 342-356.

Dell'Anno, R., \& Davidescu, A. A. (2018). Estimating shadow economy in Tanzania: An analysis with the MIMIC approach. Journal of Economic Studies, 45(1), 100-113.

Dell'Anno, R., \& Davidescu, A. A. (2019). Estimating shadow economy and tax evasion in Romania. A comparison by different estimation approaches. Economic Analysis and Policy, 63, 130-149.

Farzanegan, M. R., Hassan, M., \& Badreldin, A. M. (2020). Economic liberalization in Egypt: A way to reduce the shadow economy?. Journal of Policy Modeling, 42(2), 307-327.

Frey, B. S., \& Weck-Hanneman, H. (1984). The hidden economy as an 'unobserved'variable. European economic review, 26(1-2), 33-53.

Goel, R. K., \& Nelson, M. A. (2016). Shining a light on the shadows: Identifying robust determinants of the shadow economy. Economic Modelling, 58, 351-364.

Hajilee, M., Stringer, D. Y., \& Metghalchi, M. (2017). Financial market inclusion, shadow economy and economic growth: New evidence from emerging economies. The Quarterly Review of Economics and Finance, 66, 149-158.

Hassan, M., \& Schneider, F. (2016). Modelling the Egyptian shadow economy: A currency demand and a MIMIC model approach.

Hoinaru, R., Buda, D., Borlea, S. N., Văidean, V. L., \& Achim, M. V. (2020). The impact of corruption and shadow economy on the economic and sustainable development. Do they "sand the wheels" or "grease the wheels"?. Sustainability, 12(2), 481.

Jöreskog, K. G., \& Goldberger, A. S. (1975). Estimation of a model with multiple indicators and multiple causes of a single latent variable. Journal of the American Statistical Association, 70(351a), 631-639.

Macias, J. B., \& Cazzavillan, G. (2010). Modeling the informal economy in Mexico. a structural equation approach. The Journal of Developing Areas, 345-365.

Mazhar, U., \& Méon, P. G. (2017). Taxing the unobservable: The impact of the shadow economy on inflation and taxation. World Development, 90, 89-103.

Orviska, M., Čaplánová, A., Medved, J., \& Hudson, J. (2006). A cross-section approach to measuring the shadow economy. Journal of Policy Modeling, 28(7), 713-724.

Ramlall, I. (2016). Applied structural equation modelling for researchers and practitioners: Using $R$ and Stata for Behavioural research. Emerald Group Publishing.

Richards, T. J., \& Jeffrey, S. R. (2000). Efficiency and economic performance: An application of the MIMIC model. Journal of Agricultural and Resource Economics, 232-251.

Schaltegger, C. A., \& Torgler, B. (2007). Government accountability and fiscal discipline: A panel analysis using Swiss data. Journal of public economics, 91(1-2), 117-140.

Schneider, F., \& Enste, D. H. (2000). Shadow economies: Size, causes, and consequences. Journal of economic literature, 38(1), 77-114. 
Schneider, F. (2005). Shadow economies around the world: what do we really know?. European Journal of Political Economy, 21(3), 598-642.

Schneider, F. (2009). Size and development of the shadow economy in Germany, Austria and other OECD-countries. Revue économique, 60(5), 1079-1116.

Schneider, F. (2010). The influence of public institutions on the shadow economy: An empirical investigation for OECD countries. Review of Law \& Economics, 6(3), 441-468.

Schneider, F., Buehn, A., \& Montenegro, C. E. (2010). New estimates for the shadow economies all over the world. International Economic Journal, 24(4), 443-461.

Schneider, F., \& Williams, C. (2013). The Shadow Economy. The Institute of Economic Affairs. Retrieved on July, 26, 2016.

Schneider, F., Raczkowski, K., \& Mróz, B. (2015). Shadow economy and tax evasion in the EU. Journal of Money Laundering Control, 18(1), 34-51.

Smith, P. (1994). Assessing the size of the underground underground economy: the Canadian statistical perspectives. Ottawa: Statistics Canada.

Tanzi, V. (1999). Uses and abuses of estimates of the underground economy. The economic Journal, 109(456), F338-F347.

Tiszberger, M. G. (2019). Shadow Economy Index-Lessons from Hungary. In Societal Entrepreneurship and Competitiveness. Emerald Publishing Limited.

Torgler, B., \& Schneider, F. (2009). The impact of tax morale and institutional quality on the shadow economy. Journal of Economic Psychology, 30(2), 228-245.

Zellner, A. (1970). Estimation of regression relationships containing unobservable independent variables. International Economic Review, 11(3), 441-454. 